\title{
Rattan Batik: Local Wisdom-based Rattan Furnitures Finishing Industry
}

\author{
Sumarno $^{1}$, Dharsono ${ }^{2}$, Guntur $^{3}$, Agung Purnomo ${ }^{4}$, and Bagus Wahyu Setyawan ${ }^{5}$ \\ \{sumarno@isi-ska.ac.id ${ }^{1}$, bagusws93@gmail.com ${ }^{5}$ \} \\ ${ }^{1,2,3,4}$ Graduate School of Institut Seni Indonesia (ISI) Surakarta, Indonesia \\ ${ }^{5}$ Universitas Sebelas Maret Surakarta, Indonesia
}

\begin{abstract}
Generally speaking, rattan furnitures industry is left one step behind compared to wood furniture industry. The way to solve this issue lays on the need of innovation on product development. Production aspect is one of aspects in rattan furniture industry that needs attention. This study aims to develop the rattan furniture products, especially the finishing aspect by applying batik technique. This study applies descriptive-qualitative approach. The research method used is batik technique experiment method on rattan laminating method. The techniques include pattern designing, nyanting I, coloring I, nyanting II, coloring II; nglorod; drying; coating. The results shows that batik technique can be applied in rattan furniture industry by creating some adjustments compared to batik on cloth. The adjustements applied on dipping stage by pelorodan (peeling off the wax) by flushing, and laminating as the final process so that the color and pattern will not fade. Batik can be applied on rattan by making some adjustments, mainly on the characteristics of the materials and process efficiency efforts rattan batik furniture industry.
\end{abstract}

Keywords: rattan batik, rattan furniture, local wisdom, rattan finishing industry

\section{INTRODUCTION}

Rattan is one non-wood commodity in industry mainly used in furniture and handicrafts industry [1] [2]. In Indonesia, rattan started to get sold since 16th century [3] and by 18th century rattan product had been developed [4] and exported to foreign countries. Rattan furniture and handicraft industry in Indonesia becomes the superior product by reaching US\$ 2.3 million in 2016 and 2,4 million in 2017 [5]. The productivity of rattan furniture industry in Indonesia, however, still left one step behind compared to wood furniture industry. The percentage of comparison is $59,5 \%$ on wood furniture industry, $8,1 \%$ on metal, $7,8 \%$ on rattan, $2,3 \%$ on plastics, $0,5 \%$ on bamboo, and $21,3 \%$ on other materials [6]. Rattan furniture industry in Indonesia has high chance in development because Indonesia is the country with the biggest amount of rattans in the world, even supplying the world rattan by $90 \%$. In Indonesia, according to guidance map of cluster development on furniture industry, the obstacles that must be faced are related to designing, marketing, producing and technology, and the capital. It is further mentioned by Hidayat [7] that finishing production aspect is one of furniture industry weaknesses in Indonesia. 
Finishing as the last stage of processing the raw material into becoming the finished product, has decorative and protective functions. Decorative function is an extra credit on the appearance of a product to appear more aesthetic by using color, pattern, clear or doff [8]. The effort to develop the rattan furniture in finishing stage especially on coloring and pattern designing aspects which is interesting to developed is the application of batik technique on rattan material. Batik is method of creating patterns/design on the fabric surface using wax resist techniques. The origin of the word batik is thought to be derived from the Javanese amba (to write) and titik (point) which also envisages the whole operation [9]. Batik which take root on the local traditions now have been obtained the recognition from UNESCO in the group The Representative List of Intangible Heritage of Humanity generated by the Indonesian Nation [10].

Batik technique has not only on cloth material but also on wood, bamboo, hides, paper, earthenware and also rattan material [11]. Batik technique can be applied on wood, bamboo, hides, paper, earthenware and also rattan material because these materials have pores to absorp the wax. This study aims to find out the application of batik technique on rattan materials as an alternative for rattan furniture industry. Furthermore, in this study will be explain about the implementation of batik technique in some rattan furniture in Indonesia. Rattan furniture which implemented by batik technique expect can compete in global furniture industrial.

\section{RESEARCH METHOD}

This study is an experimental study of applying the batik technique on rattan material for rattan furniture design. Aim of this research is develop the finishing method for rattan furniture using batik technique. Types of experiment used is experiment-development to test, to check or to prove a hypothesis [12]. The result of experiment of batik on rattan will be the basis of batik application in designing rattan furniture products especially on the finishing stage. Batik process includes the pattern making, nyanting I, coloring, nyanting II, pelorodan I, nyanting III, pelorodan and nyanting and they will be continuosly done based on the color desired, pelorodan $I I$, washing and drying [13]. By estimating the product efficiency, the batik techniques applied are the simplest ones such as: (a) pattern designing, (b) nyanting I, (c) coloring, (d) nyanting II, (e) coloring II, (f) nglorod, (g) drying, (h) final laminating. After did and implemented batik technique into some rattan furniture product, then doing the Focus Group Discussion before dissemination the product. Focus Group Discussion conducted by invite some expert which are expert of Batik, expert of interior design, expert of product analysis, and some expert of furniture industrial. Furthermore, rattan batik method could be used as one of finishing method in rattan industrial to develop the rattan industrial furniture based on local wisdom.

\section{RESULT AND DISCUSSION}

Batik experiment is done on rattan core or rattan poles. Rattan core is the hardest skin called peripher or cortex [1] that has been peeled off by polishing it. Corepeel is type of rattan core or pitrit that has been peeled off or skinned off [13]. The chosen material is rattan core because batik technique required the wax absorption into the pores. It is recommended to do the batik processing by canting on the flat surface. Rattan furniture design with rattan laminating is deemed appropriate to apply the batik technique [14]. Batik equipment for finishing rattan furniture includes canthing, pan, electric stove, tub and scoop. The material needed are wax batik and batik coloring material.

The outline on the production stage of rattan furniture industry stated by Chai, et al [15] includes component making, manufacturing, ornament making, coloring and finishing [16]. In details, it includes stages of chemical treatment, sizing, sanding I, cutting, steaming, bending, 
adjusting, sanding II, assembling, QC 1, burning, sanding 3, staining, sealing-1, sealing -2, sanding IV, top coating, QC-2, packing. In staining stage, batik technique can be used as an alternative product development to develop the product on its decorative aspect.

There is an adjustment required on technique and the material used. Rattan corepeel is chosen because there are pores to absorp the wax. The flat surface is required in order to use the drawing technique with canthing. Rattan laminating is suitable media for batik technique. Laminating is sheet or board stacked or glued together, which is made of wood, iron, plastics, etc. Laminating with rattan as the raw material can be in form of bar or sheet [17].

Laminating in furniture industry is divided into laminating in form of boards or bar and direct laminating. Rattan laminating can be done by pressing, applying glue or by nailed it. The experiment of batik technique application on rattan are as follows.

\subsection{Pattern Making}

Batik sketching is the beginning of batik making by drawing a picture with a pencil on paper or directly on the material with scale $1: 1$ as the pattern [18]. Pattern is the guidance in batik making [19]. Batik pattern in Indonesia is categorized into geometry and non-geometry pattern [20]. The pattern chosen for rattan material is non-geometry pattern (lung-lungan) because it is possible for a simpler design and bigger in size and easier to produce.

\subsection{Nyanting.}

Nyanting is the pattern making and ngiseni stage. Ngiseni is filling out the emptied part of the pattern. Rattan laminating is the combined square rattan in longitudinal way, making it like a board. An adjustment in nyanting is necessary because there are interlines between rattan. The skill in operating canting is needed to produce an aesthetic and neat rattan furniture.

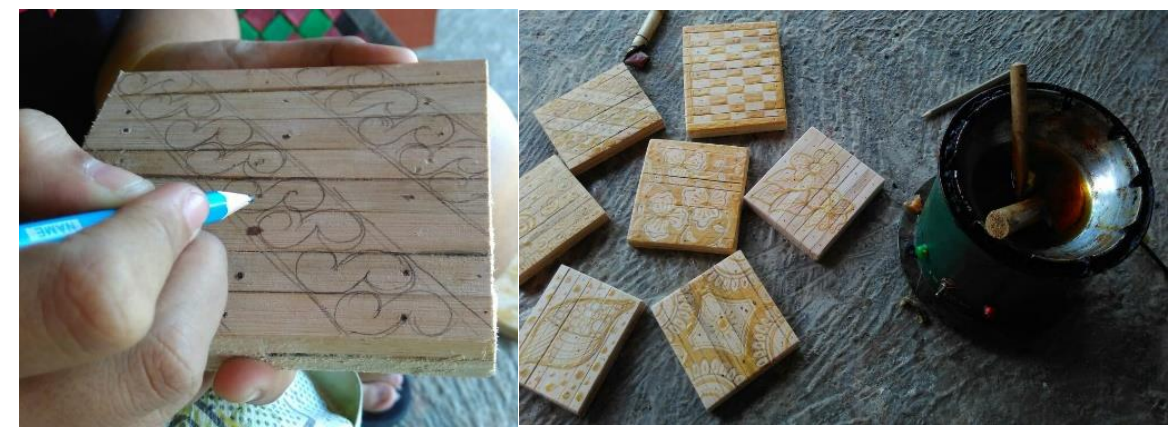

Fig. 1: Experiment in making batik pattern and the latter result of canting technique.

\subsection{Coloring $\mathbf{I}$.}

(Doc: Sumarno 2016).

Rattan coloring can increase the aesthetic level and economy level of a product. Color becomes one of quality requirement and selling point in the market [21]. The application of batik technique on rattan furniture may result on colorful pattern and appearence. Batik coloring is divided into natural coloring or synthetic coloring. Natural coloring for rattan furniture takes weeks to be done and the result of the coloring is not sharp enough [22]. Therefore the synthetic coloring is chosen by applying it with a brush. Using brush enables the applying of different color in the same time. 


\subsection{Nyanting II.}

Nyanting II is the stage where the liquidated wax is poured into the non-coloured or the coloured parts. It is neccessary to do so to protect the area or to avoid part from getting colored during dipping or flushing stage.

\subsection{Coloring II.}

The coloring is done by boiling, dipping or flushing the material. Since the material used is rattan, the coloring process is done by flushing it in the tub. This way is advantegous because the colored area is big enough or as the background of batik pattern.

\subsection{Pelorodan and Kerok Process.}

Pelorodan is done to get rid of the wax, usually done by dipping or boiling the material [23]. However, this step cannot be done to rattan material because it will: (a) loose the boards, (b) the color changes due to the heat (c) the nails or the bolts will get rusted (d) the glue gets loose. Therefore, pelorodan for rattan material is done by flushing it with hot water. The rest of the wax can be scraped off with a knife or similar tools.

\subsection{Drying.}

The next crucial step is drying. It is done to avoid the material being decayed or to avoid the fungus growth. The product dryness is important in exporting product due to the climate differences among countries. The recommended dryness level for rattan furniture is $8-14 \%$.

\subsection{Coating.}

Coating in the finishing stage is important to increase the durability of natural beauty from affecting climate [24]. Rattan batik furniture needs coating to protect the color and pattern during operasional furniture process especially to avoid frictions among furnitures. Varnishes present different levels of gloss depending on their type and application system. It was shown that polyurethane and polyacrilic resins retained a high gloss even under thermal stress conditions, while for powder coatings a low gloss level was found [25] [26]. The coating is done by using the water base, melamine or nitricellulose materials.

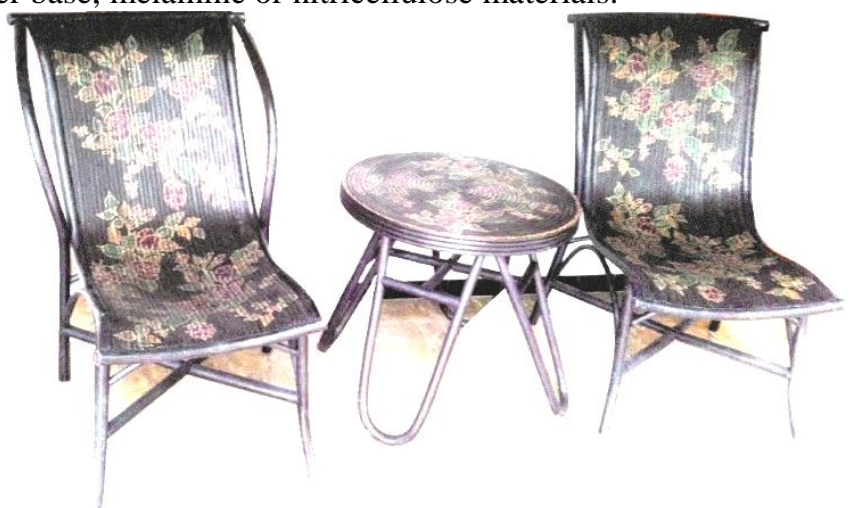

Fig. 2: Rattan furniture with batik finishing (Sumber: Sumarno 2018) 


\section{CONCLUSION}

The productivity of rattan furniture industry has not yet developed and the efforts to increase the competitiveness level of a product, especially finishing aspect is being done. Finishing work on rattan furniture industry on the staining stage, especially in coloring aspect and pattern aspect can be develop by using batik technique. Laminating is recommended for applying batik technique. Generally, the rattan furniture product is not interesting enough because it is still produced in natural or solid color. By applying batik technique, the color and pattern for rattan furniture may be developed with limitless use of color and pattern.

\section{REFERENCES}

[1]. O. Rachman, and Jasni, Rotan Sumberdaya, Sifat dan Pengolahannya, Jakarta: Badan Penelitian dan Pengembangan Kehutanan, 2013.

[2]. J. Dransfield, O. Florentino, Tesoro, and N. Manokaran, ed., Rattan Current research, Issues and Prospects for Conservation and Sustainable Developmen. Rome: Food and Agriculture Organization of the United Nations, 2000.

[3]. A. T. Tellu, Indonesia Rattan Innovation Centre, Palu: PIRNAS, 2014.

[4]. T. S. Raffles, The History of Java, Yogyakarta: Narasi, 2014.

[5]. A. Sobur, "Living Indonesia, Uniqueness of Asian Furniture and Craft", Uniqueness of Asian Furniture and Craft, 2018.

[6]. M. Jamaludin, B. A. T. Firdaus, and A. Subkiman, "The Influence of Scandinavian Furniture Design in the Development of Modern Rattan Furniture in Indonesia", Journal of Arts and Humanities, 7(3), pp. 19-26, 2018.

[7]. M. S. Hidayat, "Peta Panduan (Road Map) Pengembangan Klaster Industri Furniture." Peraturan Menteri Perindustrian Republik Indonesia. No. 90/M-Ind/Per/2011, 2011.

[8]. A. N. R. Pazon, and J. M. P. Del Rio, "Materials, Functions and Weaving Patterns of Philippine Indigenous Baskets", Asian Journal of Multidisciplinary Studies, 1(2), 2018.

[9]. S. R. Maulik, L. Bhowmik, and K. Agarwal. "Batik on Handloom Cotton Fabric with Natural Dye", Indian Journal of Traditional Knowledge 13 (4) (Oktober), pp. 788-94, 2014.

[10]. N. Kusumawati, A. Kistyanto, and S. Muslim, "The Effect of Blending Composition against Latched Power and the Resistance of Batik Wax Against Cracking and Alkaline Chemicals", International Journal on Advenced Science Engineering Information Tecnology 7 (4), pp. 2088-5334, 2017.

[11]. N. Shaari, and K. A. A. Abd Rahman, "Sustaining Batik Craft Design in Malaysia using Indigenous Creative Knowledge”, Pertanika Journal Social Sciences and Humanities 25, pp. 81-88, 2017.

[12]. P. Cash, and T. Stanković, Experimental Design Research. Disunting oleh Mario Štorga. Switzerland: Springer International Publishing, 2016.

[13]. Kasmudjo, Rotan dan Bambu Kelapa, Kelapa Sawit, Nipah, Sagu. Yogyakarta: Cakrawala Media, 2013.

[14]. A. Mulyono, M. Kubo, F. Terauchi, and T. Tauchi, "Investigation into Laminated Bamboo Fabrication by Small Industry for Product Development", Journal of the Science of Design, 1(2), pp. 231-240, 2018.

[15]. C. Chai, D. Shen, D. Bao, and L. Sun, "Cultural Product Design with the Doctrine of the Mean in Confucian Philosophy" The Design Journal, 21(3), pp. 371-393, 2018.

[16]. S. Dipodiningrat and Y. E. B. Istoto, Manajemen Industri Hasil Hutan. Yogyakarta: Pustaka Pelajar, 2016. 
[17]. J. C. de Moraes Sá, R. Lal, C. C. Cerri, K. Lorenz, M. Hungria, and P. C. de Faccio Carvalho, "Low-carbon agriculture in South America to mitigate global climate change and advance food security", Environment international, 98, pp. 102-112, 2017.

[18]. I. Soesanti and R. Syahputra, "Batik Production Process Optimization Using Particle Swarm Optimization Method", Journal of Theoretical and Applied Information Technology, 86(2), pp. 272, 2016.

[19]. Guntur, S. Marwati, and R. A. Sugihartono, "Hare as a Motif of Batik in Mojokerto.” Arts and Design Studies, vol. 37, pp. 44-49, 2015.

[20]. I. Nurhaida, A. M. Hong Wei, Zen Zen, R. Manurung, and A. M. Arymurthy, "Texture Fusion for Batik Motif Retrieval System", International Journal of Electrical and Computer Engineering (IJECE) Vol. 6, No. 6, (Desember), pp. 74-87, 2016.

[21]. M. Waty, “Airbrush Karawo Batik Design”, Journal of Social Science Studies, 6(1), pp. 128-140, 2019.

[22]. R. Raycheva and D. Angelova, "Woven Furniture Design: In Search of Form and Texture", Pro Ligno, 13(4), 2017.

[23]. S. N. Izzah, P. Marwoto, and R. S. Iswari, "Markisa Fruit (Passiflora Edulis Var. Flavicarpa) as a Fixation Material of Natural Colour of Mangrove Waste on Batik” Journal of Physics: Conference Series, Vol. 983, No. 1, pp. 012009, 2018.

[24]. P. Evans, S. Vollmer, J. Kim, G. Chan, and S. K. Gibson, "Improving the Performance of Clear Coatings on Wood through the Aggregation of Marginal Gains", Coatings, 6(4), pp. 66, 2016.

[25]. E. A. Salca, T. Krystofiak, and B. Lis, "Evaluation of Selected Properties of Alder Wood as Functions of Sanding and Coating", Coatings, 7(10), pp. 176, 2017.

[26]. K. Saddhono, S. T, Widodo, M. T. Al Makmun, and M. Tozu, "The study of philosophical meaning of batik and kimono motifs to foster collaborative creative industry." Asian Soc. Sci. vol. 10 no. 9 pp 52-61, 2014 